\title{
地震時における柔剛混合構造せん断型多層骨組の損傷集中特性 DAMAGE CONCENTRATION CHARACTERISTICS OF FLEXIBLE-STIFF MIXED SHEAR-TY่PE MULTI-STORY FRAMES UNDER EARTHQUAKES
}

\author{
高 橋 誠*, 秋山、宏*** \\ Makoto TAKAHASHI and Hiroshi AKIYAMA
}

\begin{abstract}
The energy input to the structure exerted by an earthquake is the most important quantity as a loading effect against the structure. The total energy input of a structure by an earthquake is the same amount as the energy absorbed by the structure. And the total energy input is a very stable amount which is manly influenced by the total mass and the fundamental natural period of the structure. The total damage of structures under earthquakes can be clearly described by the energy spectrum governed by the total mass and fundamental natural period of the structure, irrespective of the structural behaviors being elastic or inelastic. On the other hand, the damage distribution of multi-story' frames is very sensitive to the strength distribution of structures. The flexible-stiff mixed structure, which is composed of flexible elements with law rigidity and large elastic deformation capacity, and stiff elements with high rigidity and high energy absorption capacity, can be considered to be a preferable structural form in efficiency of energy absorption. The relationship between the maximum deformation and cumulative inelastic deformation of the flexible-stiff multi-story shear type frames were obtained already. In this paper, the damage concentration characteristics of flexible-stiff mixed multi-story shear type frames are made clear. The most important parameter, which governs the damage concentration characteristics, is the shear stress ratio between the flexible elements and stiff elements.
\end{abstract}

keywords : energy spectrum, damage distribution, multi-story frames, flexible-stiff mixed structure, damage concentration characteristics, shear stress ratio エネルギースペクトル, 損傷分布, 多層骨組, 委剛混合構造, 損傷集中特性, せん断力比

1. 序

地震に対する建物の抵抗力は端的に地震エネルギーの吸収能 カとして捉えることができる。従来の耐震設計は、積載荷重を含 む建物の重量を支える構造骨組に、地震エネルギー吸収能力を賦 与する形で行われてきた。建物の倒壊に関わるような強震時にお いては、建物重量を支える構造骨組それ自体が塑性化することに よるエネルギー吸収に、地震に対する抵抗力を期待していた。こ の設計手法は、強震時においては骨組が吸収するエネルギーに応 じた損傷を骨組自体が受けることを許容し、それによって建物の 倒壊と云った人命に関わるような事態の発生を回避しようとする 理念に基づいた方法であると言える。

このような耐震設計手法では、建物に要求される耐震性能に対 して、以下のような問題点が挙げられる。

・主要構造骨組が塑性化する為、その修復には技術的, 経済的 に困難を伴う場合がある。

・強度を上げることで塑性化を軽减する事が可能となるが、強 度を高めることは、剛性の増大につながり、加速度応答が増

し、結果として得られる利点が少ないことがある。

大きく塑性化する部材ないし層と、殆どあるいは全く塑性化 しない部材ないし層との見極めが困難な為、多くの構造部材
に相応のエネルギー吸収能力を持たせる必要がある。それに より、建物全体としてのエネルギー吸収能力は大きなものと なることが見込めるが、その大きなエネルギー吸収能力が有 効に発揮されないまま、一部の部材ないし一部の層のエネル ギー吸収能力がその限界に達することで、建物の耐震性が支 配されることが多くある。

これらの問題点は、主に建物重量を支持し小さな水平剛性を有 し地震時にも塑性化しない構造要素（柔要素）と、建物重量を支 える役割を担わず柔要素と比べて大きな水平剛性を有し地震時に は弾塑性挙動をし地震入力エネルギーを吸収する構造要素（剛要 素あるいはエネルギー吸収要素）とで骨組を構成することによ? て解決することが可能となる。このような構造形式は委剛混合構 造と呼ばれている1),2),3)。近年急速に発達した構造形式として免震 構造がある。免震構造における免震層は、建物重量を支える要素 として積層ゴムアイソレータ（柔要素に相当）を用い、地震エネ ルギーを吸収する要素 (剛要素) として鉛ダンパー,スチール弾 塑性ダンパー等を用いる采剛混合構造の一形態であると言える。

委剛混合構造は地震時においては水平剛性の小さな柔要素の弾 性挙動により、層としての復元力特性に原点への指向性が生じ、 最大変形の進行が抑制され、また地震終了時の残留変形も低减さ
* 東電設計蛛技術開発本部土木技術部 博士(工学)

** 日本大学総合科学研究所 教授.工博
Civil Engıneerıng Dept, Advanced Engineerıng Operation Center, Tokyo Electric Power Service Com, Ltd, Dr Eng

Prof, Graduate School of Science and Technology, Nihon Univ, Dr Eng 
れる ${ }^{4), 5), 6) 。}$

せん断型多層骨組の多くは様々な強度, 剛性を持った部材で構 成されており、広い意味ではすべて柔剛混合構造と見なすことが できるが、柔犅混合構造を意図的に導入しなければその利点を引 き出すことは難しい。委剛混合構造を積極的に導入した設計を行 うことにより、免震構造に対してだけでなく、一般の構造物に対 しても優れた耐震性能を持たせることが可能となる。

柔剛混合構造における柔剛各要素に期待する構造的役割は次 のように要約することができる。

・禿要素は主として建物の重量を支え、地震時において低い水 平剛性の基で弾性挙動し、剛要素のエネルギー吸収効率を高 める役割を担う。

・剛要素は初期的には高い水平剛性を確保した上で強震時には 弾塑性挙動することによって、地震入力エネルギーを吸収す る役割を担う。

禾剛混合構造の利点は次のように要約することができる

・塑性化する要素と塑性化しない要素とを明確に見極められる 為、設計の自由度が增す。

·地震入力エネルギーの吸収効率が高まる。

・エネルギー吸収要素をディバイスとして骨組内の適所に組込 む方式を採れば地霞終了後の修復は損傷を受けたデイバイス を交換することにより容易に行える。

・最大層間変形, 残留変形が抑制される。

地霞下における委剛混合構造のエネルギー応答と最大変形応 答との関係は文献(4)で明らかにされている。本論文でも文献(4) で述べられている禿剛混合構造の応答を特徵づけるパラメーター に着目した解析を行う。文献(7)では本論文と同様の手法におい て得られた禿剛混合構造の損賃集中特性に関して一部が述べられ ており、また文献(8)では委要素も塑性化するモデルに対してそ の損傷集中特性が述べられているが、本論では香要素は弾性に限 定して、より多くのパラメータを対象とした解析を行い、委剛混 合構造の損傷集中に関する基本特性を一般的に述べるものとする。

\section{2. 柔剛混合構造の基本構成}

禾剛混合構造の復元力特性を模式的に図 1 に示す。(a)図は柔要 素の対するものであり、横軸 $\delta$ は水平変位、縦軸 $Q_{f}$ は水平変位 $\delta$ に対応する柔要素の負担せん断力である。 $k_{f}$ は柔要素のバネ 定数である。(b)図は剛要素に対するものである。 $Q_{s}$ は水平変位 $\delta$ に対応する剛要素の負担せん断力である。， $Q_{Y}$ は剛要素の降 伏せん断力であり、, $\delta_{Y}$ は ${ }_{s} Q_{Y}$ に対応する剛要素の降伏変位で ある。 $k_{s}$ は剛要素の弾性時のバネ定数である。剛要素の復元力 特性は完全弾塑性型で代表している。(c)図は染剛各要素の復元 力特性を合成したものであり、正,負の最大変形が等しい場合が 例示されている。縦軸 $Q$ は柔要素と剛要素の負担せん断力の和 である。 $Q_{Y}$ は剛要素が降伏する時の水平変位 $\delta_{Y}={ }_{5} \delta_{Y}$ に対応す る柔要素負担せん断力と剛要素の負担せん断力の和であり、層と しての降伏せん断力に対応する。 $k_{f}$ は柔要素のバネ定数と同一 である。

(c)図に示す地震応答下における水平変位 $\delta_{m}$ 時に着目すれば、 入力されるエネルギーの一部は剛要素に塑性歪エネルギーとして
吸収されると共に、他の一部は弾性歪エネルギーとして柔要素に 蓄えられる(斜線部)。エネルギーが急激に入力する場合には、一 般に層間変位が大きくなり、剛要素の損傷（エネルギー吸収）も 急激に増大寸ることになるが、同時に柔要素に蓄えられる弾性歪 エネルギーも増大する。この弾性歪エネルギーは、復元力特性に 原点への指向性を增大させる効果をもたらし、変形の進行を抑制 させると共に、正,負两方向の塑性変形量を均一化させる効果も もたらす。結果として、同一のエネルギー入力に対して最大変形 が抑制され、塑性変形の片寄りが減少し、剛要素のエネルギー吸 収効率が高まる効果をもたらす4),5)。またこの原点指向性は、地 震終了時の残留変形を減少させる効果も持つ6)。

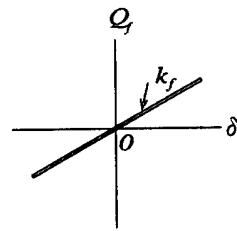

(a)

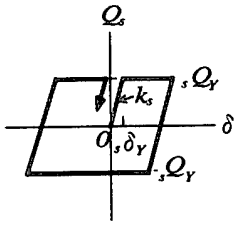

(b) 郕要素 (弾塑性要素)

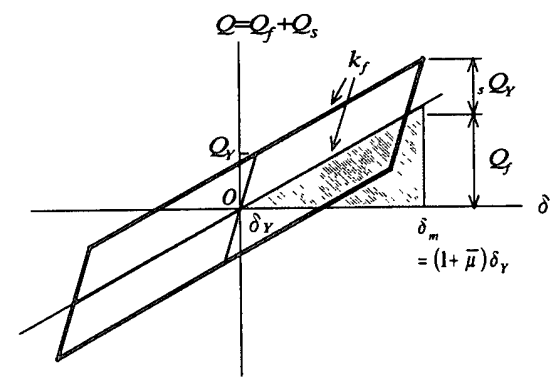

(c) 合成効果

図 1 柔剛混合構造の復元力特性

鋼構造を対象とすれば、正,負の絽返し変位振幅を受ける鋼素 材の終局エネルギ一吸収能力は、変位振幅の大きさとの関係で評 価する場合、必ずしも直線関係ではないが、大局的に図2の様に 示されることが、実験的に明らかとなっている9。

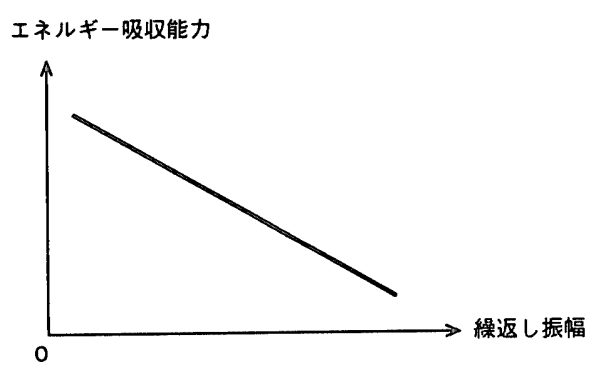

図 2 エネルギー吸収能力と繰返し変位振幅との関係

鋼素材の特性は、座屈,破断等の不安定現象を除けば、鋼部材， 銅骨組に対しても基本的に備わっているものである。地霆動下に おいて、繰返し変位振幅が小さい応答の場合には部材が発揮でき る終局エネルギ吸収能力は大きなものとなり、変位振幅が大きい 応答の場合にはそれが小さくなることを図 2 は示している。 
禿剛混合構造は、既述のように、柔要素の弾性挙動により変 形の進行が抑制され、その結果、エネルギー吸収要素が発揮でき る終局エネルギー吸収能力を大きなものとすることができる構造 形式である。柱, 梁骨組を柔要素として重力に対して弾性設計し、 剛要素に相当する地震エネルギー，吸収機構をその骨組の適所に設 けることにより、委剛混合構造骨組を構筑することが可能となる。

制震ディバイスとしてスチールスリットダンパー，鋼製せん 断パネル，各種アンボンドブレース，粘性ダンパー等のエネルギ 一吸収要素を骨組各部に組込み、他の構造要素を弾性に留めよう とする制震構造と呼ばれる構造形式も、多くの場合、委剛混合構 造として地震応答特性を述べることができる。

\section{3. 解析モデル及び用いる地震動記録}

禿剛混合構造せん断型多層骨組を解析対象とする。解析モデル は図3の様に表される。

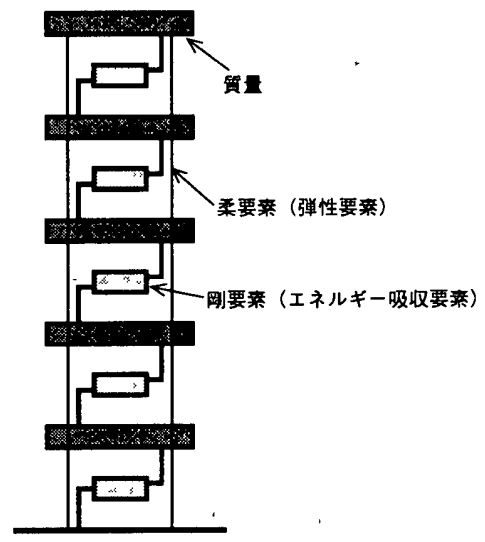

図 3 解析モテル

地震時における柔剛混合構造の変形応答を特徵づけるものは、 次式に示す委剛要素間の剛性比 $r_{k}$ 、及び柔剛要素間の負担せん 断力比 $r_{q}$ である ${ }^{4)}$ 。

$$
\begin{aligned}
& r_{k}=\frac{k_{f}}{k_{s}} \\
& r_{q}=\frac{Q_{f}}{{ }_{s} Q_{Y}}
\end{aligned}
$$

図1に示す平均最大変形応答下 $\delta_{m}=(1+\bar{\mu})_{s} \delta_{y}$ における負担せん 断力比 $r_{q}$ は、 $Q_{f}=(1+\bar{\mu}) k_{f s} \delta_{Y}$, 及び, $Q_{Y}=k_{s s} \delta_{Y}$ であるから次式 のように表現できる。

$$
r_{q}=(1+\bar{\mu}) r_{k}
$$

ここで、 $\bar{\mu}=\frac{\mu^{+}+\mu^{-}}{2}:$ 平均塑性変形倍率

$\mu^{+}=\frac{\delta^{+}-\delta_{Y}}{{ }_{s} \delta_{Y}}:$ 正の荷重領域にお汁る塑性変形倍率 $\mu^{-}=\frac{\delta^{-}-\delta_{\gamma}}{{ }_{s} \delta_{Y}}:$ 負の荷重敛域における塑性変形倍率 $\delta^{+}, \delta^{-}:$正, 負の荷重領域の最大変位

剛性比 $r_{k}$ は柔要素のみのバネによる固有周期 $T_{f}$ （秒）と剛要
素のみのバネによる固有周期 $T_{s}$ （秒）で与えられる。表1には解 析に用いた $T_{f}, T_{s}$ が示されている。 $T$ (秒) は采剛要素を合成 した場合の固有周期である。表中の $T_{f}=100.0$ (秒) $，{ }^{\prime} r_{k}=0.0$ の 行は柔剛混合構造ではない場合に対応する。合成周期は 0.5 秒か ら2.28秒迄となっており、中低層建物の標準的な固有周期を含む 範囲と言える。解析モデルの層数 $N$ はこれら中低層の建物を代 表するものとして $5,10,20$ 層を操っている。一うの $T$ ，持つ解析 モデルに対して複数の強度レベル, 複数の損傷集中レベル, 複数 の損傷集中層を与えている。パラメータの変化による応答值の影 響を明確に抽出するため解析モデルはできる限り単純なものとす る。各層の柔剛比 $r_{k}$ は全層に亘って一定とする。高さ方向の質 量分布は一定とする。剛要素の復元力特性は完全弾塑性型とする。 入力エネルギーはすべて㓝要素の履歴で吸収されるものとするこ とで、損賃と入力を一体的に評価する。したがって粘性減衰は無 いものとす:る。

表1 固有周期 (秒)

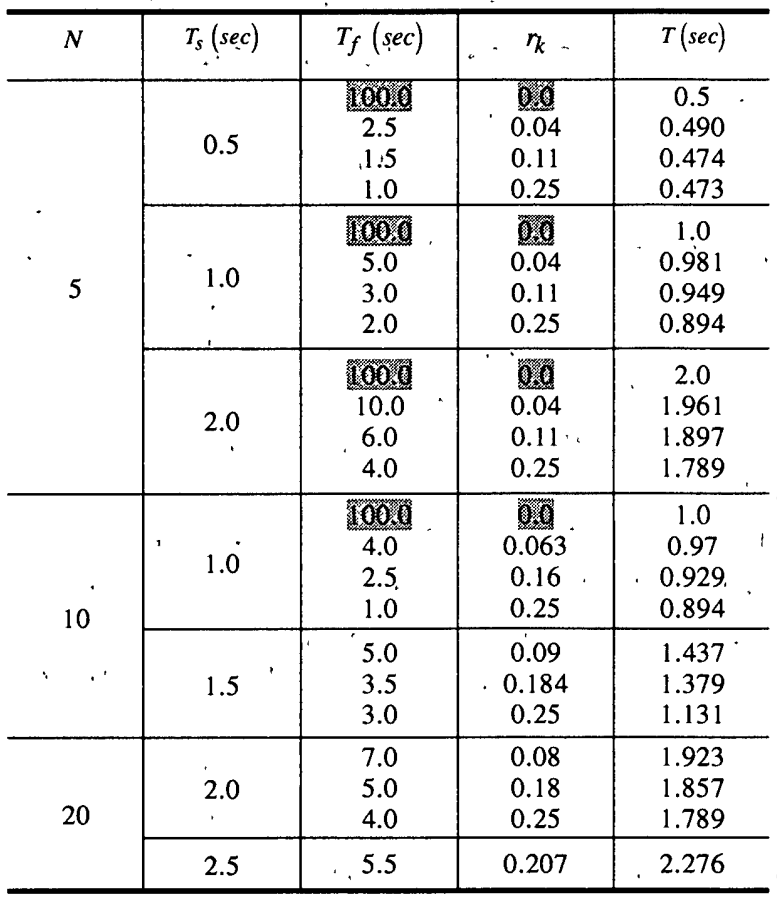

本論文では地震動特性の異なる3記録を入力地震波として用い ている。一つの地震動に対する弾塑性系へのエネルギー入力は、 臨界減衰比 $h=0.1$ の 1質点弾性系のエネルギースペクトルで代表 できることが解っている1)。図4に解析に用いる3波の $h=0.1$ の1 質点弾性系に対するエネルギースペクトルを示す。縦軸は総エネ ルギー入力の次式による速度換算值である。横軸 $T$ は固有周期 である。

$$
\begin{gathered}
V_{E}=\sqrt{\frac{2 E}{m}} \cdots \\
E=-\int_{0}^{r_{0}} m \dot{z_{0}} \dot{y} d t: \text { : 総エネルギー入力 } \\
m: \text { 質点の質量, } z_{0}: \text { 地動加速度, } \\
t_{0} \text { : 地動継続時間, } y: \text { 質点の相対変位 }
\end{gathered}
$$




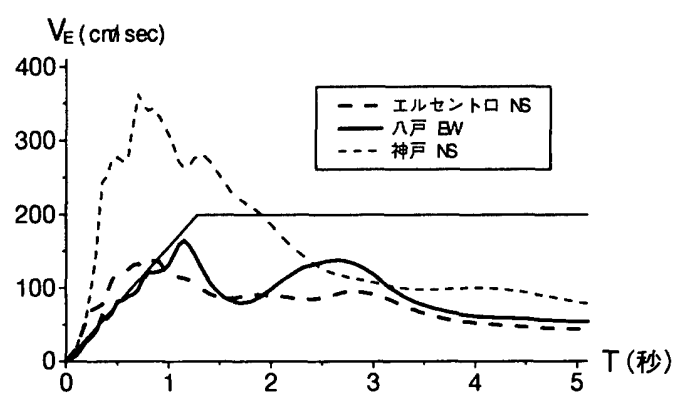

図 4 エネルギースペクトル

図の太破線は1953年Imperial Valley地震エルセント記録NS成分 （エルセントロNS），太実線は1968年十勝沖地震八戸記録EW成 分 (八戸EW)，細破線は1995年兵庫県南部地震神戸海洋気象台 記録NS成分（神戸NS）に対するものである。細実線は「建築基 準法」に示される第3種地盤における2次設計用加速度応答スペ クトルをエネルギースペクトルに換算して示したものである10)。 短周期領域において神戸NS波の入力が非常に大きいことが示さ れている。

図5にはエルセントロNS, 八戸EW, JMA神戸NSの各地震記録に よる時刻歷エネルギー入力曲線を例示する。地震動継続時刻 $t$ における総エネルギー入力 $E(t)$ を地霞終了時の総エネルギー入力 $E$ に対する比率として表したものである。太実線は $h=0.1$ ， $T=1.0$ の 1 質点弾性系の時刻歴入力曲線であり、曲線上の○印 は最大層間変位発生点である。細実線は $N=5$ で $T=1.0$ の無減 衰完全弾塑性系に対する時刻歴入力曲線であり、○印は各層の最 大層間変位発生点である。

図示のように時刻歴入力曲線は地霞動により異なる。神戸波 の入力は極めて急激であるが八戸波はそれに比べて緩やかであり、 エルセントロ波はその中間的であると言える。また、10\%減衰 の1質点弾性系と5質点弾塑性系の時刻歴入力曲線は、同一の固 有周期の場合、対応性があると言える。エネルギー吸収能力と共 に設計に際して重要な応答最大変位は 1 質点系の場合、の印の様 に、急激に入力エネルギーが増大する時間に発生する。多質点系 の場合は○印の様に各層の最大変位の発生が一時期に集中すると は限らない。

本論文では、地震動の入カレベルに対する解析モデルの強度 レベルが同一の固有周期を持つ系に対して地震動の違いによらず ほほ一定となるように、次式で得られるベースシア係数を用いて モデルの基準強度を定めている。

$$
\alpha_{1}=\alpha_{r} \times \frac{2 \pi V_{E}(T)}{g T}
$$

$$
\text { ここで、 } V_{E}(T) \text { : エネルギースペクトルから得られる固有周期 }
$$$$
T \text { に対応する入力エネルギー }
$$

$\alpha_{r}$ : 強度係数

$g:$ 重力加速度。

(5)式の右辺乗算の第2項は $V_{E}(T)$ に対応する弾性限界のベース シア係数 $\alpha_{e}$ をええる。

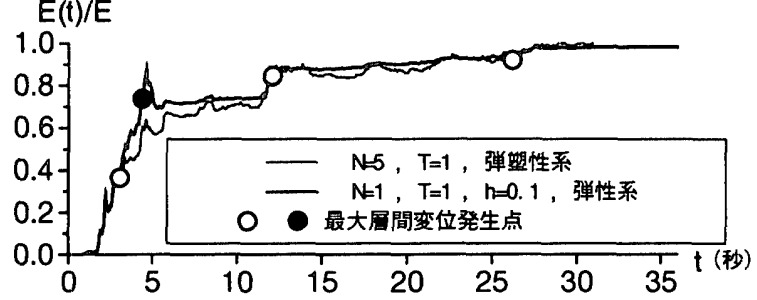

(a) El Centro NS
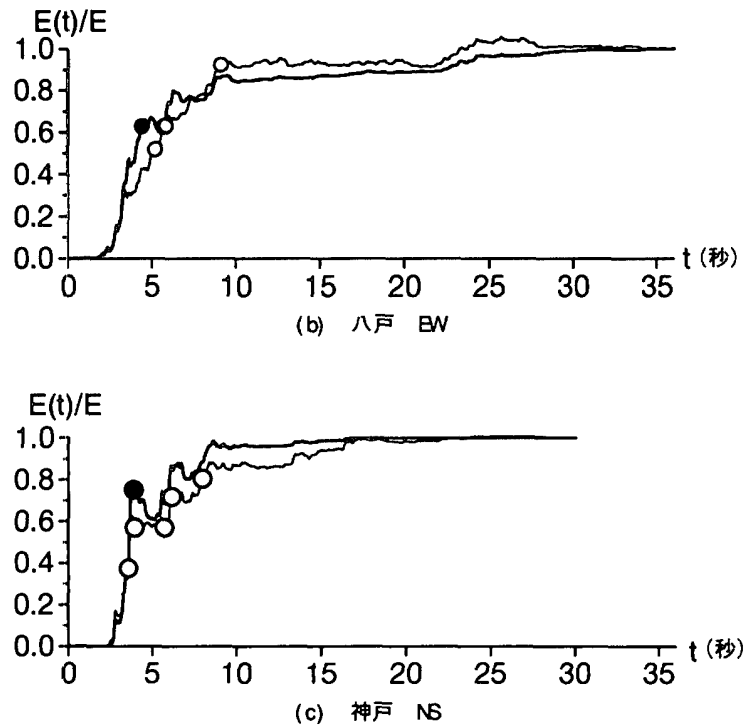

図 5 時刻歴エネルギー入力

応答解析に際して、解析モデルの変形限界, エネルギー吸収 限界は復元力特性上には与えず、入力エネルギーのすべてが弾塑 性履歴で安定的に吸収されるものとする。したがって、解析結果 における吸収エネルギーがエネルギー吸収能力あるいは所要エネ ルギー吸収量と解釈される。すなわち、解析モデルの塑性化レベ ルは強度をパラメータとして䟼与することになる。(5)式におけ る強度係数 $\alpha_{r}$ は次の(6)式に示す3通りを基本値としているが、 他に $\alpha_{r}=\{0.15,0.2\}$ の場合もある。これらにより、次節で述べる 損傷集中指数 $n$ を求める際の基準モデルにおいて、平均塑性変 形倍率 $\bar{\mu}$ の応答解析值が一桁前半から10乃至20、非常に大きい 場合は30台に亘る範囲を網羅することになる。(3)式に示した $r_{q}$ の応答值は、損傷集中が存在するモデルで0から4.0程度, 極端に 大きい場合は8程度となることもある。

$$
\alpha_{r}=\{0.05,0.1,0.3\}
$$

(5)式における $V_{E}(T)$ を得るための $T$ は表1に示される合成固有 周期 $T$ を用いる。

\section{4. 基本損傷集中則 ${ }^{1)}$}

層の復元力特性が完全弾塑性型であるせん断型多層骨組の損 傷分布の予測值は次式で与えられる

$$
\frac{W_{p l}}{W_{p}}=\frac{s_{l} p_{l}^{-n}}{\sum_{i=1}^{N} s_{l} p_{l}^{-n}}
$$


ここで、 $W_{p t}: i$ 䊬の損傷 $， w_{p}=\sum_{i=1}^{N} w_{p}:$ 骨組全損傷 $p_{1}=\frac{\alpha_{i}}{\alpha_{1} \cdot \bar{\alpha}_{1}}:$ 强度低下率

$\alpha_{i}=p_{i} \alpha_{1} \bar{\alpha}_{i}:: i$ 層の降伏せん断力係数

$\bar{\alpha}_{i}:$ 最適降伏せん断力係数分布

$\boldsymbol{n}:$ 損傷集中指数

$s_{1}=\left(\sum_{j=1}^{N} \frac{m_{J}}{M}\right)^{2}\left(\frac{k_{1}}{k_{t}}\right)^{2} \bar{\alpha}_{t}^{2}$

$m$ ：：多質点振動系に置換する際のノ質点の質量

$N$ :層数 $, M=\sum_{j=1}^{N} m,:$ 総質量 $\cdots$

上式における $\bar{\alpha}_{1}$ は各層の累積塑性変形倍率がほほ一定となる 降伏せん断力係数分布である。 $i$ 層の累積塑性変形倍率 $\eta$ 、は次 式で与えられる。

$$
\eta_{1}=\frac{W_{p}}{Q_{r_{t}} \cdot \delta_{v_{r}}}
$$

ここで、 $Q_{r}: i$ 層の降伏耐力

$\delta_{r_{t}}: Q_{r}$ に対応する $i$ 層の降伏変位

(8)式は着目する層の履歴吸収エネルギーが、完全弾塑性系に おけるー方向の塑性変形で吸収されるとした場合の塑性変形量を、 弾性限変形に対する比として表したものと同一である。

(7)式中の $p_{1}$ は、損賃集中要因を耐力低下で評価方場合の $i$ 層の耐力低下率を示すものである。損賃集中指数 $n$ は $p$ 、よよる $i$ 層への損傷集中に及ほ感度を示すものと言え、nの值が大きい ほど損鹪集中が起こりやすいことを示す。柱降伏型骨組に対して は $n=12$ が、梁降伏型骨組では $n=6$ が提案されている(11).12)。 $n$ 值は $p_{1}$ に依存する。 $p_{i}$ に対応する損傷集中要因を $p_{d}$ とした場合 の $p_{d}$ と $n$ 值との関係は、柱降伏型骨組の場合次式で与えられる ${ }^{13)} 。$

$$
n=6+23 p_{d}^{6}
$$

禾剛混合構造に対しても損傷分布を(7)式で表現できるものと して、損傷集中指数 $n$ を応答解析により求好。 $n$ 値は着目す る一つの層に降伏耐力の低下をもたらした場合の損傷分布の変 化から次の上うに求められる13。

はじめに、着目する $k$ 層の損傷分布の応答解析により求めこ れを基準系の応答值 $\boldsymbol{a}$ とする。 $a$ は(7)式より次式で表される。

$$
\frac{W_{p k}}{W_{p}}=a=\frac{s_{k} p_{k}^{-n}}{\sum_{i=1}^{N} s_{i} p_{t}^{-n}} .
$$

次に、着目する $k$ 層のみの降伏耐力を $p_{d}(<1.0)$ 倍した場合の損 傷分布を応答解析により求め、これを損傷集中系の応答值 $b$ とす る。bは次式で表される。

$$
\frac{W_{p k}}{W_{p}}=b=\frac{s_{k} p_{k}^{-n} p_{d}^{-n}}{\sum_{i \neq k} s_{t} p_{t,}^{-n}+s_{k} p_{k}^{-n} p_{d}^{-n}} .
$$

(10),(11)式よりnは次式で求められる。

$$
n=-\ln \left\{\frac{b(1-a)}{a(1-b)}\right\} / \ln p_{d}
$$

\section{5. 柔剛混合構造の損傷集中特性}

\section{$5-1$ 強度低下率と損傷集中指数}

図5は(10)式から(12)式を用いて得た㸴数 $N=5$ におけ方損傷集 中指数 $n$ の応答解析值と強度低下率 $p_{d}$ との関係を示している。

(12)式を用いる際の基染系の応答值 $a$ は、各層の累積塑性変形 倍率がほほ一定となるように、ベースシア係数を除く各層の降伏 せん断力係数 $\alpha$ 、修正を加えながら、繰返し計算を行うことで 求めている。損傷集中系の応答値 $b$ を求める際には、着目する $k$ 層の強度のみを低下させ、バネ定数は変化させない。すなわち系 の応答特性を変化させることになる固有周期の変化は行わないも のとしている。
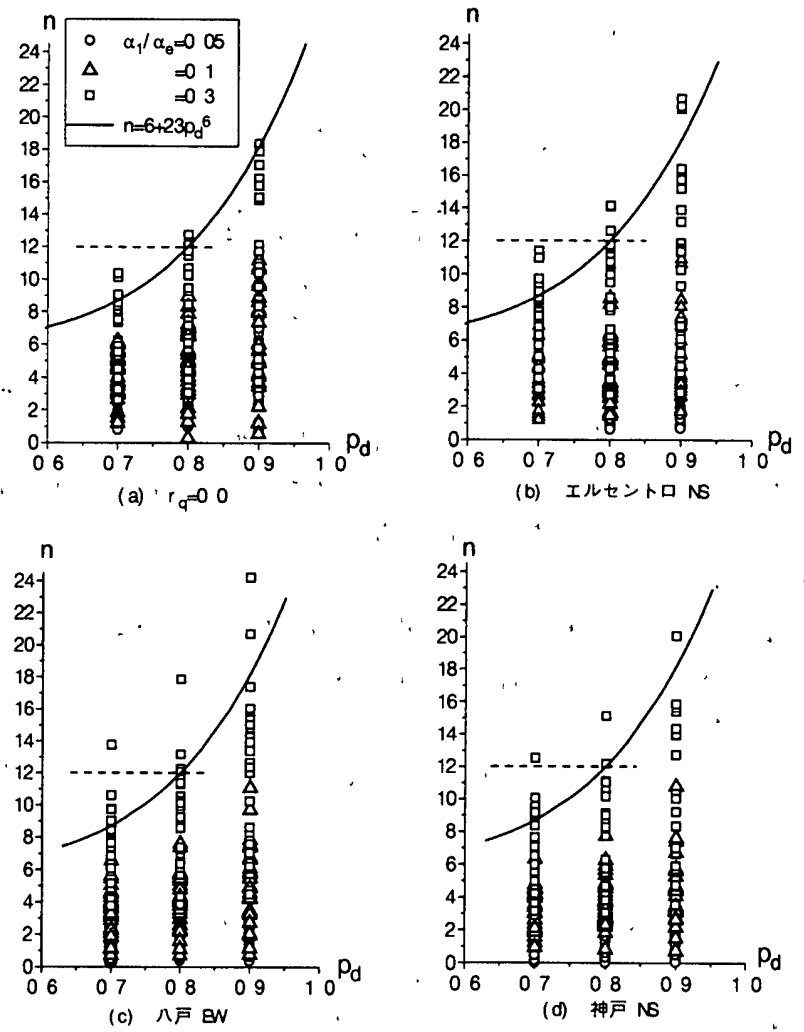

図 $5 \quad n-p_{d}$ 関係

図5 (a)は柔剛混合構造ではない柱降伏型骨組の場合であり、用 いた3地霞動記録による值をまとめて示している。(b), (c), (d) 図 は柔剛混合構造の場合で、それぞれエルセントロNS, 八戸EW,神 戸NSによる值である。解析モ゙デルの強度レベルよ、一つの固有周 期を持つモデルに対して(6)式に示す 3 通りで、○、、，ロはそれぞ $れ \alpha_{r}=0.05,0.1,0.3$ の場合に対応する応答解析值である。実線は(9) 式で与えられる $n$ 値の上限値である。眓示のように $n$ の值は $p_{d}$ の大きさに依存する。3 割程度の耐力低下に相当する損傷集中要 因が存在する場合を想定すれば、椇傷集中指数の上限値としては 
約 $n=9$ が与えられ、一方、耐力低下が1割とした場合には $n=18$ 程度とすることで損傷集中の上限を評価することができる。また、 $n$ 值は(5)式における強度係数 $\alpha_{r}$ にも依存し、 $\alpha_{r}$ が大きい場合 にその值が大きくなる。これは、高強度の構造物が損傷集中に不 利であることを意味するものではない。強度が変化しても固有周 期が変わらなければエネルギー入力は変化しないので、(8)式に 示すように強度が大きくなれば、累積塑性変形倍率 なる。基準モデルに拈けるク、が小さい系に損儩集中要因が存在 すると $n$ 值が大きくなることを示すものである。

図6は八戸EW波に対する累積塑性変形倍率 $\boldsymbol{\eta}$ と $n$ 值の関係の応 答值を例示したものである。層数 $N=5$ で固有周期が $T=1.0$ (秒)， 強度低下率が $p_{d}=0.8$ の場合である。 $\eta$ は基準系における值であ る。図示のように $\eta$ が小さい場合に $n$ 值が大きくなる傾向が示さ れている。

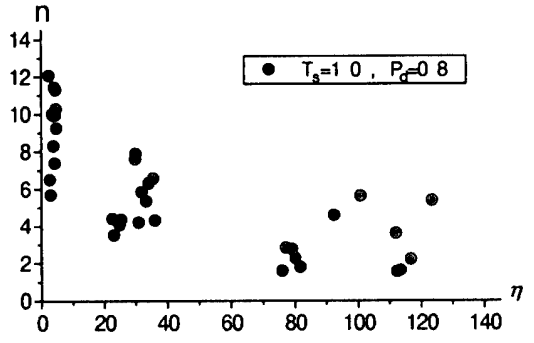

図 $6 n-\eta$ 関係

表 2 は、(12)式を用いて得られた損傷増加率を示したものであ る。表中の $a$ は基準系における損傷分布であり、b/aは損傷集 中要因を与えた場合の損傷分布の $a$ に対する比率である。同じ $n$ 値であっても損傷集中要因 $p_{d}$ の值および $a$ の值により損傷增加 率は変化する。例えば $p_{d}=0.9$ の場合には(9) 式および図 5 の様 $に p_{d}=0.7, p_{d}=0.8$ の場合と比べて $n$ 值は大きくなるが、損傷 增加率は同一の $a$ 及び同一の $n$ 值に対して $p_{d}=0.6, p_{d}=0.7$, $p_{d}=0.8$ の場合より小さい値となっている。また、 $p_{d}$ 及び $n$ 值 が同一の場合、 $a$ の值が小さい場合に損傷增加率が大きいことが 示されている。

図 7 は、損傷集中層の損傷の骨組全体の損傷に対する比率を 示したものである。図中の $a$ 及び $b$ は表 2 の場合と同様に着目 する層の基準系の損㩐分布と損傷集中系の損傷分布である。横軸 に損傷集中要因 $p_{d}$ を採って表している。 $b$ を求める際の $n$ 値は 応答値の上限値を与える $(9)$ 式で与える。

耐震安全性の観点からは、一つの層に多くの損傷が集中する ような場合を想定した設計を行う必要がある。そのような損傷集 中として $b \geq 0.6$ を考慮すれば、耐力低下率として $p_{d}=0.8$ を探 ることができる。全損傷の 8 割の損傷が集中する場合でも、基準 系で 2 割以上の損傷を想定する系においては、同様に $p_{d}=0.8$ を 採ることができる。一方、損傷集中要因は材料強度のバラッキ， 使用部材サイズの整理等の要因等により生じ、それを強度低下率 として換算すれば、およそ $15 \%$ 程度 $\left(p_{d}=0.85\right)$ と見積もること ができるり。これらにより、損傷集中要因による耐力低下率とし て $p_{d}=0.8$ を採用し、それを基本値として採用することは耐震設 計の観点から有効であると言える。
表 2 損甥增加率 $b / a$

\begin{tabular}{c|c|c|c|c|c}
\hline \multirow{3}{*}{$a$} & \multirow{2}{*}{$n$} & \multicolumn{4}{|c}{$b / a$} \\
\cline { 3 - 6 } & & $p_{d}=0.6$ & $p_{d}=0.7$ & $p_{d}=08$ & $p_{d}=0.9$ \\
\hline \multirow{4}{*}{0.1} & 2 & 2.36 & 1.85 & 1.48 & 1.21 \\
& 6 & 7.04 & 4.86 & 2.98 & 1.73 \\
& 12 & 9.81 & 8.89 & 6.18 & 2.82 \\
& 16 & 9.97 & 9.71 & 7.98 & 3.75 \\
\hline \multirow{5}{*}{0.2} & 2 & 2.05 & 1.69 & 1.40 & 1.18 \\
& 6 & 4.21 & 340 & 2.44 & 1.60 \\
& 12 & 4.96 & 4.74 & 3.92 & 235 \\
& 16 & 4.99 & 4.93 & 4.49 & 2.87 \\
\hline \multirow{5}{*}{0.4} & 2 & 1.62 & 1.44 & 1.28 & 1.13 \\
& 6 & 2.34 & 2.12 & 179 & 1.39 \\
& 12 & 2.49 & 2.45 & 2.27 & 1.76 \\
& 16 & 2.50 & 2.49 & 2.40 & 1.96 \\
\hline \multirow{5}{*}{0.6} & 2 & 1.34 & 1.26 & 1.17 & 1.08 \\
& 6 & 1.61 & 1.55 & 1.42 & 1.23 \\
& 12 & 1.664 & 1.65 & 1.59 & 1.40 \\
& 16 & 1.666 & 1.66 & 1.64 & 1.48 \\
\hline \multirow{5}{*}{0.8} & 2 & 1.15 & 1.11 & 1.08 & 1.04 \\
& 6 & 1.24 & 1.21 & 1.17 & 1.10 \\
& 12 & 1.249 & 1.245 & 1.23 & 1.17 \\
& 16 & 1.250 & 1.248 & 1.24 & 1.19 \\
\hline
\end{tabular}

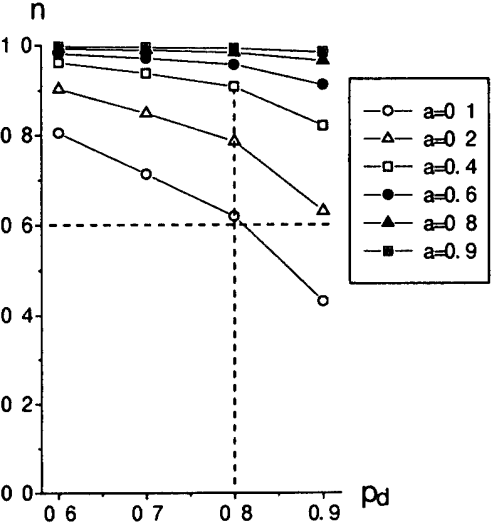

図 7 損甥集中層の損稫分布

\section{5 -2 負担せん断力比 $r_{q}$ に着目した $n$ 值}

柱降伏型骨組における耐力低下係数 $p_{d}$ と損傷集中指数 $n$ との 関係は(9)式で与えられるが、柔剛混合構造の場合には柔要素の 弾性挙動により特定層への損傷集中が緩和されること期待でき、 (9)式をそのまま柔剛混合構造に適用することは損傷集中を過剩 に見積もることになり設計の合理性に欠ける。柔剛混合構造の地 震時挙動を特徵づけるパラメータは、既述のように柔剛要素間バ ネ定数比 $r_{k}$ と負担せん断力比 $r_{q}$ であり、これに着目して柔剛混合 構造の $n$ 値を求める。

図8は $p_{d}=0.8$ における $n-r_{q}$ 関係を示したものである。解析モ デルの層数 $N$ は 5 の場合である。 $\bigcirc, \Delta, \square$ は強度係数 $\alpha_{r}=\alpha_{1} / \alpha_{e}$ がそれぞれ $0.05,0.1,0.3$ の場合である。地震記録 3 波 による解析値をまとめて表している。図における $r_{q}=0$ は采剛混 合構造ではない場合に対応する。いずれの地震波に対しても禿剛 要素間の負担せん断力比 $r_{q}$ の增大に伴い $n$ の上限値及びバラッキ 幅が減少し、 $r_{q} \geq 20$ の領域で $n \leq 2.0$ となっている。 $n=2.0$ は表 2 に示すように損傷增加率が相対的に少ない場合に相当する。 


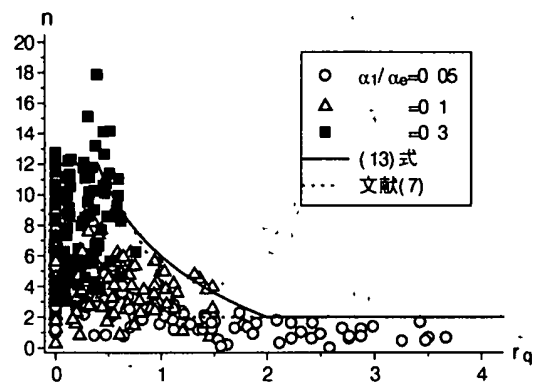

図'8 $r_{q}-n$ 関係 $\left(N=5, p_{d}=0.8\right)$

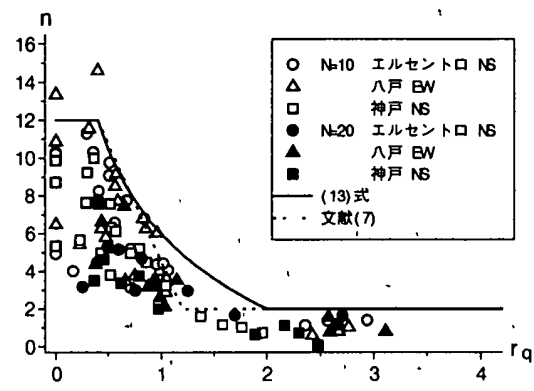

図 9, $r_{q}-n$ 関係 $\left(N=10, N=20 p_{d}=0.8\right)$

図には次式による $r_{q}$ に对する $n$ 值の上限が実線で示されている。

$$
\left.\begin{array}{lll}
r_{q}<0.4 & \text { の場合 } & n=12 \\
0.4 \leq r_{q}<2.0 & \text { の場合 } & n=-32+38 r_{q}^{-0 ! 6} \\
r_{q} \geq 2.0 & \text { の場合 } & n=2.0
\end{array}\right\} \text {; }
$$

(13)式の值は $0.4 \leq r_{q}<2.0$ の範囲において文献(7)で示される $n$ 值よりも大きな值となうているが基本特性に大きな違いは無い。 図9は同様に $p_{d}=0.8$ における層数が $N=10, N=20$ の場合の $r_{q}-n$ 関係でありり、この場合にも $n$ の上限值として(13)式が適用 できる。図8,図9より、はり降伏型骨組における $n=6.0$ は柔剛混、 合構造における $r_{q}=1.0$ の場合に対応していると言える。

図10は強度低下率 $p_{d}$ の違いに着目した $N=5$ の場合の $n-r_{q}$ 関 係を示している。 $\bigcirc, \Delta$, 口はそれぞれ $p_{d}$ が0.7, 0.8, 0.9の場合で ある。(a)図はエルセントロNS波に対するものであり、(b),(c)図 はそそれぞれ八戸EW波, JMA神戸NS波に対するものである。図5で 述べだように $n$ は $p_{d}$ ，増加関数であり、図10に示される様に $r_{q}<0.4$ の領域でその傾向が見られるが、 $r_{q}$ の増大に伴ってその 傾向は減少し、 $r_{q}>0.5$ の領域で $p_{d}$ の違いの影響はほとんどな くなっている。 $n$ の上限值は(13)式で表わされる。この傾向の地 震波の違いによる影響は受けない。

図11には塑性化レベルに着目した $n-r_{q}$ 関係を示しててい。層 数 $N$ は5 5 場合である。 $\bigcirc, \Delta$, 口は塑性化レベルを与える強度係 数 $\alpha_{1} / \alpha$ がそれぞれ0.05, 0.1, 0.3の場合である。強度レベルが大 きく基本的に損賃レベルが小さい場合、即ち図の $\alpha_{r}=\alpha_{1} / \alpha_{e}=0.3$ 場合、 $r_{q}$ の小さな領域において $n$ の忘答値が大きな值となってい る。上限值は(13)式で代表できる。この傾向は地震波の違いによ る影響は受けない。 。

図12は損傷集中層 $(\mathrm{k}$ 層)に着目したものである。 $\mathrm{O}, \Delta, \mathbf{D}$ れぞれ損傷集中層が1, 3, 5層の場合の応答值である。 $r_{q}<0.5$ 程 度の範囲において、同一の $r_{q}$ に対して最上層への集中が若干少な いと言える。これは一つの層に損集を集中させる様なエネルギー 集中型骨組を設計する場合、損賃集中層を最上層とすることは多 少効率が悪くなる可能性の存在を意味すると言える ${ }^{14)} 。 r_{q}>0.5$ の領域では層による違いは無くなる。地震波による違いは、神戸 NS波で最上層への損傷集中が多少大きくなる傾向が見られるが 大きな違いはないと言える。 $n$ 值の上限值は(13)式で代表できる。

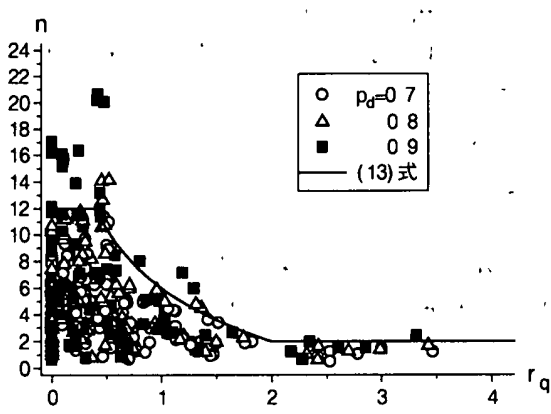

(a) エルセントロ NG

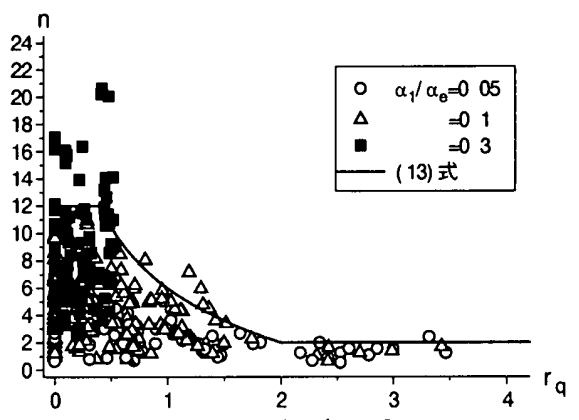

(a) エルセントロ NG

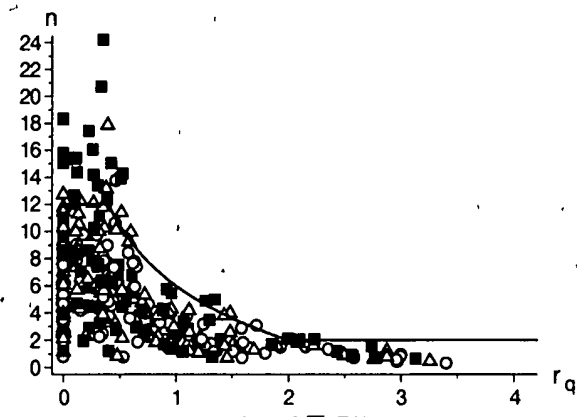

(b) 八戸 $\mathrm{EW}$

図10 $r_{q}-n$ 関係 $\left(p_{d}\right.$ に着目 $)$

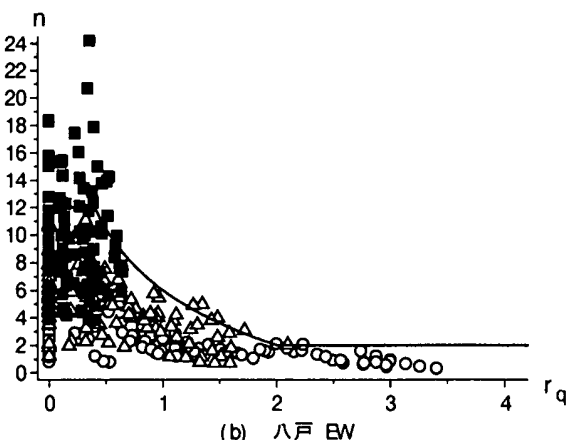

図 $11 r_{q}-n$ 関係（塑性化レベルに着目）

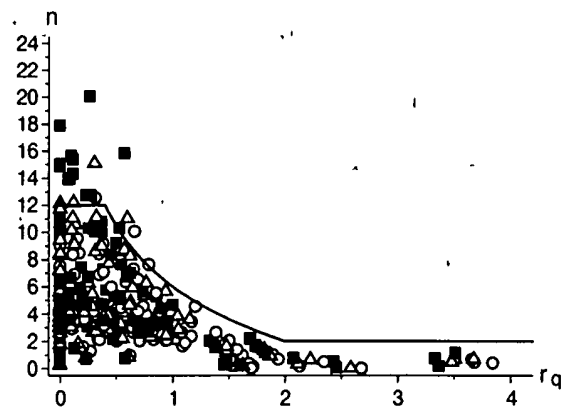

(c) 神戸 NG

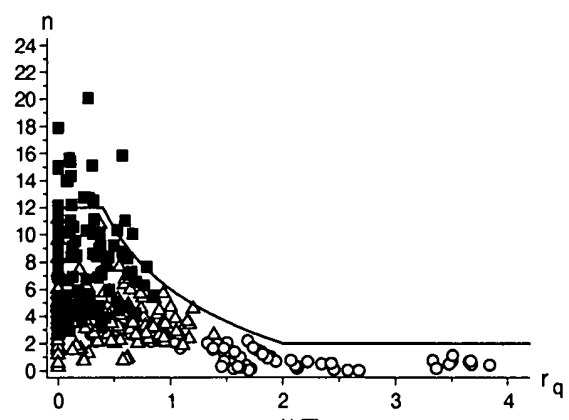

(c) 神戸 NG 


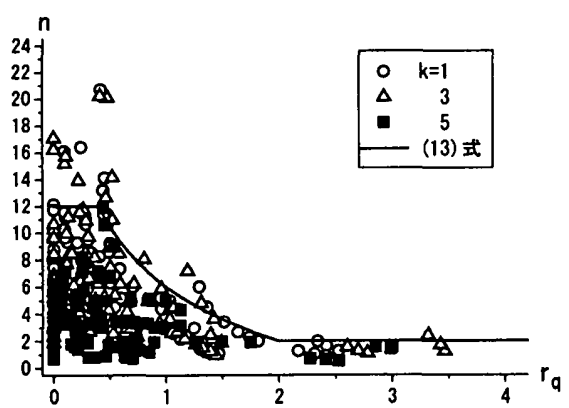

(a) エルセントロ NS

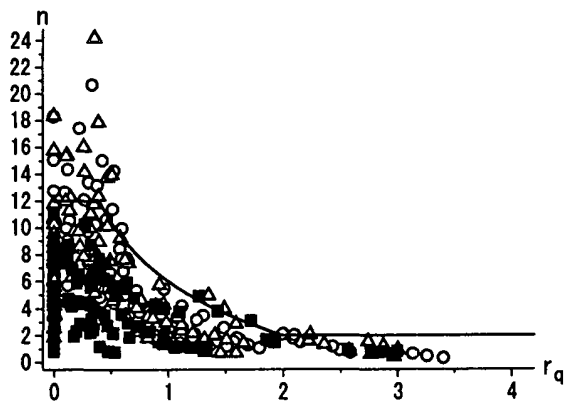

(b) 八戸 EW

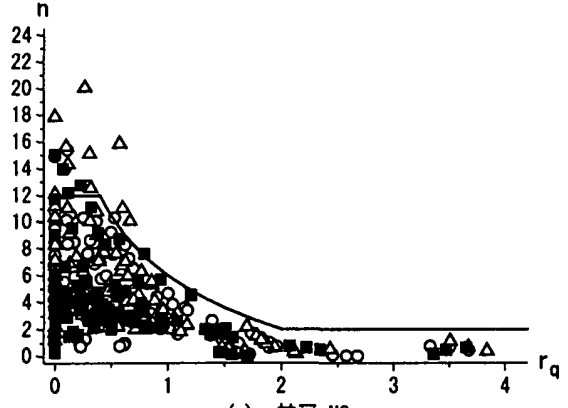

(c) 神戸 NS

図 $12 r_{q}-n$ 関係（損偒集中層に着目）

6 まとめ

柔剛混合せん断型多層骨組の損傷集中特性を地震応答解析に より明らかにした。解析に用いた地震動記録はエネルギー入力特 性の異なるエルセントロNS，八戸EW, JMA神戸NSの3波である。 剛要素の復元力特性は完全弾塑性型とした。解析モデルの層数は $5,10,20$ とした。モデルの固有周期は0.5秒から 2.28 秒の範囲とし た。応答解析結果は次のようにまとめられる。 1) せん断型骨組の一般系は柔剛混合構造と見なすことができる。 2) 柔剛混合構造を意図的に導入することにより、せん断型多層 骨組の設計に際して重要な問題となる損傷集中を制御すること ができる。

3)柔剛混合構造骨組の地震時の忘答性状を特徵づける柔剛要素間 の負担せん断力比 $r_{q}$ を用いて損傷集中を $n$ 値で評価すれば、そ れらの関係は次式で評価できる。

$$
\left.\begin{array}{lll}
r_{q}<0.4 & \text { の場合 } & n=12 \\
0.4 \leq r_{q}<2.0 & \text { の場合 } & n=-32+38 r_{q}^{-016} \\
r_{q} \geq 2.0 & \text { の場合 } & n=2.0
\end{array}\right\}
$$

4) $r_{q}$ の增大によりに伴い、 $n$ 值のバラツキ幅、最大值が減少し、 損傷集中が緩和される。

5)負担せん断力比 $r_{q} \geq 0.5$ の領域では $n$ 值は損傷集中層の違い, 地 震動の違いの影響は受けない。 $r_{q}<0.5$ の領域でもそれらの影 響は少ない。

\section{参考文䌾}

1)秋山宏・建築物の耐震極限設計 第 2版, 東京大学出版会, 1987 2)秋山宏、耐震性能の多様化に対応した耐震設計、日本建築学会構造系 睔文集 第472号，pp 85-90，1995、6月

3)原田幸博，秋山去 エネルギー集中型柔剛混合骨組の耐展設計，日本 建案学会構造系睔文集 第472号，pp.57-66，1995、6月

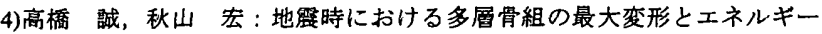
志答，日本建築学会構造系論文集，第 515 号, pp59-66, 1999.1

5)高槅 誠，秋山宏 地震時における柔剛混合せん断型多層骨組の累積塑 性変形々最大変形，日本建築学会大会学術講演梗概集，1998.B2

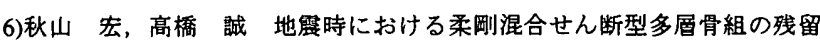
変形, 日本建築学会大会学術請演梗概集, 1998.B2

7)秋山 宏: エネルキーの验合に基づく建築物の耐震設計，技報堂出版， 1999

8 )䂙立，高檑誠，秋山宏 柔剛湿合構造多層骨組の損傷集中特性， 日本建筑学会大会学術講演梗概集, $1998 . \mathrm{Cl}, \mathrm{pp} 931.932$

9)秋山 去, 高橋 誠，石 軍・繰り返し曲げを受ける円形断面銅棒の終 局エネルギー吸収能力, 日本建築学会構造系論文集, 第 475 号, pp145$154,1995.9$

10)秋山 宏 铁骨柱脚の耐㖘設計，技報堂出版，1985 11)秋山宏・地縟時における鍓構造ラーメン骨組の損倁分布則，日本建 築学会論文報告集, 第 309 号, 1981.11

12)秋山 去 はり降伏型銅構造多層㣚接骨組の $D_{s}$ 值, 日本建築学会論 文報告集，第 332 号，pp.38-45，1983.10

13)日本建筮学会，建築酎殿設計における保有酎力と変形性能，1990 14)日本建築学会大会学術講演梗概集，1998 B2)秋山去.最上層損侮集 中型多層骨組の $D_{s}$ 值, 日本建築学会構造系論文報告集, 第 362 号, pp 37.44, 1986.4 